\title{
How Islamic Education Impacts Personal Life of Student of Senior High School?
}

\author{
Istania Widayati Hidayati ${ }^{1 *}$, Subur ${ }^{1}$, Akhmad Baihaqi $^{1}$, Afga Sidiq Rifa'i ${ }^{1}$ \\ Mujahidun $^{1}$, Tohirin ${ }^{1}$ \\ ${ }^{1}$ Department of Islamic Education, Universitas Muhammadiyah Magelang, Magelang, Indonesia \\ *Corresponding author. Email: istaniawidayati@ummgl.ac.id
}

\begin{abstract}
Senior high school students have diverse backgrounds; some of them have a strong base in the religious field; some do not. Besides, the learning of Islamic Education (IE) in SMAN uses the 2013 curriculum in contrast to IE learning in Islamic boarding schools. This study aims to explore the meaning of life from IE learning for senior high school students broadly. This study uses a qualitative approach with deep interview as a method of collecting data. The subjects of the study were students of class XII of SMAN IV, Magelang city. The results indicate that IE in SMAN IV of students' life comes from an understanding of affective religious material, not merely cognitive. Parental education and teacher modelling are the most influential factors in giving meaning to life in a student.
\end{abstract}

Keywords: meaning of life, Islamic education, teenager

\section{INTRODUCTION}

Indonesia is a nation with Muslim domination, it has a deep intension about Islamic education (IE) in the school. Curriculum 2013 (C-13) is the latest product to improve Indonesian Muslim integrity that begin from school. IE in the school beneficial as aqidah fortress, keep al-Qur'an and hadist, and the creation of individual and social transgressions. C-13 keep moral and ethical foundation in face knowledge and technology era and also meet rational and spiritual needs [1].

So far, C-13 become a change tool education in Indonesia. A lot of researches have been done to analyse the effectiveness of the performance of this curriculum, but so far, the existing research still focuses on cognitive aspects. Article by Iwan Sumiarwan discusses the Effect of 2013 Curriculum Policy on Learning Quality. This study shows that curriculum policy in 2013 has a significant positive effect on learning management to realize the quality of learning [2]. Another study written by Safitri Mardiana and Sumiyatun entitled Implementation of the 2013 Curriculum in Learning History at SMA Negeri 1 Metro. This study only describes in a descriptive way how SMA Negeri 1 Metro implemented the 2013 curriculum in learning history [3].

The next research was written by Yuna Mumpuni Rahayu entitled The Effect of Changes in 2013 Curriculum on the Development of Students, The focus of the discussion was on English IX class subjects at SMP Negeri 14 Cirebon [4]. Research on the effect of the 2013 curriculum on character formation was written by Yetty Morelent and Syofiani. Research by Handayani discusses the Effect of 2013 Curriculum on Student Learning Motivation [5].

From past research, it was found that some researchers only focus on the cognitive realm. Previous researchers have not discussed in depth whether the 2013 curriculum in the field of Islamic Education can give meaning to life.

Then, this research will discuss the extent of the impact of the 2013 curriculum on the meaningfulness of student life. The purpose of this research is to explore deeply, where exactly does the effect of change towards goodness come from? Is it true from the 2013 PAI curriculum system or are there other aspects that are more influential? This study seeks to uncover the depth of meaning of the 2013 Curriculum system which has been applied at SMAN 4 Magelang City.

\section{METHODS}

\subsection{Types of Research}

This research is a qualitative research with a phenomenological approach. Qualitative method is a method of collecting data that emphasizes its analysis in the deductive and inductive inference process and in the analysis of the dynamics of the relationship between observed phenomena, using scientific logic. According to Strauss and Corbin (2007: 1), this qualitative research is research that can be used to examine people's lives, history, behaviour, organizational functionalization, social movements, or kinship relations.

Qualitative approach according to Corbin and Strauss is a form of research in which researchers in collecting and analysing data become part of the research process as participants along with informants who provide data [6]. Meanwhile, according to Bogdan and Taylor, qualitative research is a research procedure that is able to produce descriptive data in the form of speech, writing, and behaviour of the people observed. Through this qualitative 
research it is possible to obtain an understanding of reality through the process of inductive thinking

\subsection{Research Informant}

In qualitative research, the term sample is changed to be the subject, informant, participant or research target. The author uses the term informant. The technique used to determine the subject in this study was purposive sampling. Purposive sampling is a technique for sampling data sources with special consideration. The sample in question is considered to know the most about the problem to be examined. The sample criteria in this study are:

a. school students who are Muslim,

b. has participated in teaching and learning activities in schools at least 2 years, meaning the informant is a class XII high school,

c. active activities (have a lot of experience).

\subsection{Method of Collecting Data}

\subsubsection{Interview}

In this study interviews were conducted using the semi structured interview guidelines. According to Sugiyono, a semi-structured interview is a type of interview that is included in the in-depth interview category in which the implementation is more free when compared to structured interviews [7]. The purpose of this type of interview is to find problems more openly, where the party invited to an interview is asked for opinions, ideas. In conducting interviews, researchers listen carefully and take note of informants' explanations. The interview guide material in this study was prepared based on the sources of life meaning from Roy Baumestier [8].

\subsubsection{Observation}

The type of observation used in this study is nonparticipant observation. According to Sugiyono, nonparticipant observation is that the researcher is not involved and is only an independent observer. Researchers explore the research location, and look for and pay attention to what is there. In addition, in non-participant observation the symptoms appear to be systematic and preparation so that the results obtained are more natural [7].

\subsubsection{Documentation}

According to Sugiyono, Documentation is an event that has already passed. Documents can be in the form of writings, drawings or monumental works of a person [7]. Documents in the form of writing, for example diaries, life history, stories, biographies, regulations and policies. Documentation data that will be used is in the form of photographs, live drawings, sketches and others.
Documents in the form of artwork, which can be in the form of drawings, sculptures, films and others[7].

\section{RESULTS AND DISCUSSION}

\subsection{Characteristics of the 2013 Curriculum}

The purpose of Islamic religious education in schools is as a stronghold of aqidah, maintaining the teachings of the Koran and hadith, the creation of individual and social injustice, the moral and ethical foundation in dealing with science and technology and culture and meeting the needs of being rational and supra rational [1].

The 2013 curriculum aims to prepare Indonesian people to have the ability to live as individuals and citizens who are faithful, productive, creative, innovative, and affective and able to contribute to social, national, state, and world civilization [9]. The learning process that refers to a scientific approach according to the Ministry of Education and Culture (2016) includes five steps, namely: observing, asking questions, collecting data, associating, and communicating. Explained as follows:

a. Observing, namely the activities of students identifying through the sense of sight (reading, listening), smell, listener, taste and touch when observing an object with or without tools.

b. Asking questions, namely students' activities expressing what they want to know both regarding an object, an event. The form can be a question sentence and a hypothesis sentence. The learning outcomes of the questioning activity are students can formulate problems and formulate hypotheses.

c. Collecting data, namely student activities looking for information as material to be analysed and concluded. Data collection activities can be done by reading books, collecting secondary data, field observations, trials (experiments), interviews, distributing questionnaires, and others. The learning outcomes of data gathering activities are students can test hypotheses.

d. Associating, namely student activities to process data in the form of a series of physical and mind activities with the help of certain equipment. Learning outcomes from reasoning / associating activities are students can conclude the results of the study of the hypothesis.

e. Communicate, namely the activities of students describe and convey their findings from the activities of observing, asking questions, collecting and processing data, and associating aimed at others. Submission can be done orally or in writing in the form of diagrams, charts, drawings and the like with the help of simple technological devices and or information and communication technology. The learning outcomes of communicating activities are students can formulate and account for the verification of hypotheses [9].

With this scientific approach teachers are no longer the center of education, but students as active objects in the process of knowledge transfer. The 2013 curriculum shows efforts to improve education from the government. The impact is rapidly changing the old educational paradigm that verbalism becomes more holistic. It is this flow pattern that is developed and emphasized in the 2013 curriculum, 
where the main stream emphasizes the development of student creativity and character strengthening. Variants that need to be fulfilled are the three main components that need to be internally balanced internally in learners, namely knowledge, skills, and attitudes [10].

\subsection{Meaning of Life}

The meaning of life is one of the highest needs of the hierarchy of human life needs. According to Roy Baumastier who developed the needs of Maslow's theory, it assumes that humans have four different needs to get the meaning or meaning of life:

a. Need for purpose (the need for purpose, namely the desire to connect between present and future events.) Life goals come from three sources, so in a sense every human life has three basic sources of purpose: first is nature, second is culture, and third is their own choice [11].

b. Need for value (the need for value, namely the desire that our actions have positive values). This means having a basis for knowing what is right and wrong, good and bad. 'Good' and 'bad' are among the first words children learn. They are some of the earliest and most culturally universal concepts, and among the few words that house pets sometimes acquire. In terms of brain reactions, the feeling that something is good or bad comes very fast, almost immediately after you recognise what it is [11].

c. Need for efficacy (desire to influence the environment). People like to feel that they can make a difference. Their values have to find expression in their life and work. Or, to look at it the other way around, people have to be able steer events towards positive outcomes (by their lights) and away from negative ones [11]. The meaningful life, then, has four properties. It has purposes that guide actions from present and past into the future, lending it direction. It has values that enable us to judge what is good and bad; and, in particular, that allow us to justify our actions and strivings as good. It is marked by efficacy, in which our actions make a positive contribution towards realising our goals and values.

d. Need for self-worth (the need to feel valuable, the desire that the self has a positive value). People with meaningful lives typically have some basis for thinking that they are good people, maybe even a little better than certain other people. At a minimum, people want to believe that they are better than they might have been had they chosen or behaved or performed badly. They have earned some degree of respect [11].

Roy F Baumeister said: "People ask what is the meaning of life, as if there is a single answer. There is no one answer: there are thousands of different ones. A life will be meaningful if it finds responses to the four questions of purpose, value, efficacy, and self-worth. It is these questions, not the answers, that endure and unify"[11]. It means, every people have a different way to explore their life and to produce their creation.

\subsection{Discussion}

Researchers found various data and information regarding the meaningful life of the informant. The data and information are as follows:

a. Informant 1 .

Informant 1 has the initials WBI, and serves as chairman of the student council. From the results of the interview with the first informant, the informant appeared to be a calm and friendly person. He has a great sense of responsibility in carrying out the mandate of the school organization. Informant 1 is the first child of two siblings. The heroine he idolized was the Principal himself. From the results of researchers' interviews with informant 1, the 2013 curriculum has an impact in providing meaning in life, this is due to: continuous learning, lots of presentations, lots of listening explanations from friends, and lots of practice. According to the informant, learning with a lot of practice is more understood. From the cognitive aspect, the religious knowledge controlled by informant 1 falls into the category of sufficient, although not too fluent in reading the Qur'an, the informant has made a work that is calligraphy.

Examining more deeply in the ritual practice of prayer, it turns out informant 1 still has not performed a full-time prayer, sometimes one of the prayers is missed due to fatigue or busyness. Informant 1 prefers a friendly PAI teacher. The most memorable part when studying Islamic religious education is if delivered with practice, such as the practice of body care.

b. Informant 2

Informant 2 has the initials $\mathrm{MMZ}$ and serves as the chairman of Islamic Club called ROHIS. Informant 2 is seen as a strict and passionate person. According to him, the meaningfulness of PAI was achieved depending on the teacher who brought it. Informant 2 prefers his teacher's friendly style, because it is more comfortable in communicating. In contrast informant 2 did not like teachers who were too serious. The second informant said that his religious behaviour and the concept of religious knowledge he got from his family, especially his strict father. Although not a very educated father, MMZ informant's father is actively participating in studies at NU's pesantren. From here the informant was also given additional tutoring to study the 'kitab kuning' at home. This is in accordance with his father's advice, that religious education in technological times is very important. So, the informant's father provided his son with additional religious education. As chairman of Rohis, MMZ has high personal and social influence. The product that he issued was in the form of rules that were applied to the members of the Rohis. Regarding the prayer rituals, the informants have not consistently prayed 5 times a day. This is due to busyness and laxity in activities.

From the findings of the above data, it can be seen that Islamic education in schools is not yet fully meaningful for both informants. Although there are technical aspects such as learning strategies that make students more active and creative. This is because family and friends are more dominant in influencing the understanding and religious 


\section{CONCLUSION} coloured by his closeness and communication with friends even though he also had an idol, namely his school principal. Informant 2 is more coloured by the education of fathers and family systems at home. In addition, the understanding of $\mathrm{NU}$ inherent in his family has formed a special insight into religion. This makes the material at school does not significantly influence the meaning of life of the informant. In mastering religious material in school, it still feels cognitive oriented, has not been able to touch the heart. Moreover, coupled with differences in the characteristics of religious teachers. Class X, XI and XII are taught by different teachers. If you get a teacher who you want because you have a friendly attitude, of course the informant will feel comfortable, but if you go up the class, he gets a teacher who is too serious then learning Islam becomes uncomfortable.

This proves that the spirit of a teacher is more important than the method or subject matter. Education in the time of the Apostle was very simple but succeeded in instilling strong faith in the hearts of friends [12]. The 2013 curriculum has not been able to reach the aspect of wisdom, other than because of the lack of teacher resource factors, other things are caused by:

a. Teaching material is still a reference for most teachers in teaching and does not refer directly to the main source (the Qur'an, the book, the hadith, we fiqh, the book of history).

b. The tendency of learning in the realm of cognition is still happening, this can be identified from the textbook sentence structure.

c. Lack of enrichment of experience and awareness [13]. Teachers who are supposed to be mentors are only able to show a variety of knowledge and their arguments without giving deeper meaning [13]. Real education, not only integrates religion and general science, but involves 3 elements of education. To maximize the success of the 2013 curriculum in schools, the government needs to pay attention to the quality of education in families and communities.

Family is a small part of the country which has an important pillar to educate the nation's generation. The family is a social institution that is universally multifunctional, namely the functions of supervision, social, education, religion, protection, and recreation [14]. This makes the family has a network system of interactions that are interpersonal, so that the relationships between family members become closer and more intensive [14]. Education in schools is a structured and tiered education pathway consisting of basic education, secondary education and higher education. The school aims to guide, direct and educate children in the multilevel curriculum. Humans are creatures that have the desire to unite with others and the natural environment around them [14]. By using thoughts, instincts, feelings, desires and so on humans react and interact with their environment. Patterns of social interaction are produced by continuous relationships in a society.

If education is fully integrated then students can practice the material obtained in a faster way. the compactness between schools, families and communities is the strongest fortress guarding the aqeedah and morality of the young generation of Indonesia.
From the research results it can be seen that, the system offered by the government still has shortcomings in the exemplary field. The K-13 learning strategy did indeed leapfrog far from the previous strategy. The figure of the PAI teacher turned out to have a very important role in setting an example. Teacher modelling are the most influential factors in giving meaning to life in a student.

Parental education from families turns out to have a greater influence on religious beliefs. This proves that the figure of the PAI teacher and family education has a big role in being an example of informants in SMAN 4 Kota Magelang.

\section{REFERENCES}

[1] S. Su'dadah, "Kedudukan Dan Tujuan Pendidikan Agama Islam Di Sekolah,” J. Kependidikan, vol. 2, no. 2, pp. 143-162, 1970.

[2] I. Sumiarwan, "Pengaruh Pelaksanaan Kebijakan Kurikulum 2013 terhadap Manajemen Pembelajaran untuk Mewujudkan Kualitas Pembelajaran,” Khazanah Akad., no. 2013, pp. 1-8, 2017.

[3] Safitri Mardiana and Sumiyatun, "Implementasi Kurikulum 2013 dalam Pembelajaran Sejarah di SMA Negeri 1 Metro," Historia Santiago., vol. 5, no. 1, 2017.

[4] Y. M. Rahayu, "Pengaruh perubahan kurikulum 2013 terhadap perkembangan peserta didik," Logika, vol. XVIII, no. 3, 2016.

[5] Y. Morelent, "Pengaruh Penerapan Kurikulum 2013 Terhadap Pembentukan Karakter Siswa Sekolah Dasar Negeri 05 Percobaan Pintu Kabun Bukittinggi," J. Gramatika, vol. 2, pp. 141-152, 2015.

[6] Wahidmurni, "Pemaparan Metode Penelitian Kualitatif,” p. 200, 2017.

[7] Sugiyono, Metode Penelitian Kuantitatif Kualitatif dan R\&D. Yogyakarta: Alfabeta, 2010.

[8] F. Fridayanti, "Pemaknaan Hidup (Meaning in Life) Dalam Kajian Psikologi," Psikologika J. Pemikir. dan Penelit. Psikol., vol. 18, no. 2, 2013.

[9] W. Linda, "Pendekatan Saintifik \& Model Pembelajaran K-13,” Bahastra, vol. 37, no. 1, p. 89, 2017.

[10] A. Sulaeman, "Pengembangan Kurikulum 2013 Dalam Paradigma Pembelajaran Kontemporer," Islamadina, vol. XIV, no. 1, pp. 71-95, 2015.

[11] Roy F Baumeister; Florida State University in Tallahassee, "The Meanings of Life." [Online]. Available: https://aeon.co/essays/what-is-better-ahappy-life-or-a-meaningful-one. 
2019.

12] R. A. Istania Widayati Hidayati, Wow Teacher Project. Magelang: Unimapress, 2019.

[13] I. W. Hidayati, Nalar Tasawuf sebagai Revolusi Pendidikan Islam, 1st ed. Yogyakarta: Dee Publisher,
[14] M. I. Kurniawan, "Tri Pusat Pendidikan Sebagai Sarana Pendidikan Karakter Anak Sekolah Dasar," Pedagog. J. Pendidik., vol. 4, no. 1, p. 41, 2015. 